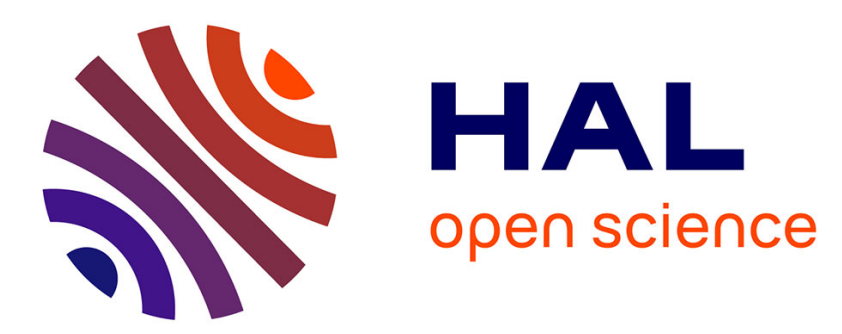

\title{
Bifunctional N-heterocyclic carbene ferrocenyl ligands - synthesis and palladium(II) complexes
}

Pauline Loxq, Jean-Claude Daran, E. Manoury, Rinaldo Poli, A. Labande

\section{To cite this version:}

Pauline Loxq, Jean-Claude Daran, E. Manoury, Rinaldo Poli, A. Labande. Bifunctional N-heterocyclic carbene ferrocenyl ligands - synthesis and palladium(II) complexes. European Journal of Inorganic Chemistry, 2015, 4, pp.609-616. 10.1002/ejic.201403001 . hal-01919613

\section{HAL Id: hal-01919613 https://hal.science/hal-01919613}

Submitted on 29 Jul 2021

HAL is a multi-disciplinary open access archive for the deposit and dissemination of scientific research documents, whether they are published or not. The documents may come from teaching and research institutions in France or abroad, or from public or private research centers.
L'archive ouverte pluridisciplinaire HAL, est destinée au dépôt et à la diffusion de documents scientifiques de niveau recherche, publiés ou non, émanant des établissements d'enseignement et de recherche français ou étrangers, des laboratoires publics ou privés. 


\title{
Bifunctional N-Heterocyclic Carbene Ferrocenyl Ligands - Synthesis and Palladium(II) Complexes
}

\author{
Pauline Loxq, ${ }^{[a, b]}$ Jean-Claude Daran, ${ }^{[a, b]}$ Eric Manoury, ${ }^{[a, b]}$ Rinaldo Poli ${ }^{[a, b, c]}$ and Agnès Labande ${ }^{*[a, b]}$
}

Abstract:

Two ferrocenylimidazolium tetrafluoroborate salts $(R=M e, 7$ and $R=$ (2,4,6-trimethylphenyl), 8), precursors of new ferrocenylimidazol-2ylidene bifunctional ligands, have been prepared for the first time. The free 1-(2-dimethylaminomethyl)ferrocenyl-3-methylimidazol-2-ylidene 12 has been isolated and characterised by ${ }^{1} \mathrm{H}$ and ${ }^{13} \mathrm{C}$ NMR and represents the second example of an isolated and characterised imidazol-2-ylidene directly linked to ferrocene. Neutral (13) and cationic (14) palladium(II) complexes have been obtained in moderate yields and have been characterised by ${ }^{1} \mathrm{H}$ and ${ }^{13} \mathrm{C}$ NMR and by mass spectrometry.

\section{Introduction}

$\mathrm{N}$-heterocyclic carbenes (NHCs) have long been considered as phosphine surrogates, however their rapid development over the past fifteen years has shown that they are much more than that..$^{[1]}$ There are numerous advantages to work with $\mathrm{NHCs}$, among them the air stability and low toxicity of their precursors (e.g. imidazolium salts) and their usually strong coordination to late transition metals, giving rise to robust, air-stable complexes. The strong $\sigma$-donating properties of NHCs combined with their fan-like geometry give them unique reactivity in catalysis, particularly in cross-coupling reactions. ${ }^{[2,3]}$ However, due to their specific geometry, the synthesis of efficient chiral NHC ligands giving high levels of enantioselectivity in asymmetric catalysis is still a challenge. ${ }^{[4]}$

We have recently reported the preparation of planar chiral ferrocenyl phosphine/NHC ligands and their use in the challenging asymmetric version of the palladium-catalysed Suzuki-Miyaura reaction. ${ }^{[5]}$ These ligands furnished good activities in the cross-coupling reaction of naphthyl bromides with napthtylboronic acid at low catalyst loadings. However, their limited success in terms of enantioselectivity prompted us to design a different family of bifunctional NHC ligands.

Since its synthesis in 1974 by Hayashi et al., ${ }^{[6]}$ the PPFA ligand has been successfully used in various reactions of asymmetric catalysis (Figure 1). ${ }^{[7]}$ We describe here a new class of ferrocene-based chiral NHCs based on the PPFA structure, and their coordination to palladium. Whereas the PPFA ligand

\footnotetext{
[a] Dr P. Loxq, Dr. J.-C. Daran, Dr. E. Manoury, Prof. R. Poli, Dr. A. Labande

CNRS, LCC (Laboratoire de Chimie de Coordination)

205 route de Narbonne, BP 44099

F-31077, Toulouse Cedex 4, France

E-mail: agnes.labande@lcc-toulouse.fr,

[b] Université de Toulouse, UPS, INPT

F-31077, Toulouse Cedex 4, France

[c] Institut Universitaire de France, 103

bd Saint-Michel, 75005, Paris, France
}

possesses both planar and central chirality, we chose to design ligands with planar chirality only, similarly to our previous phosphine-functionalized ferrocenyl NHC ligands. ${ }^{[5]}$

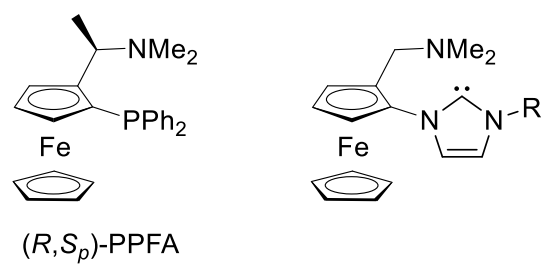

Figure 1. Left: PPFA ligand developed by Hayashi et al. ${ }^{[6]}$; right: our work.

\section{Results and Discussion}

\section{Synthesis of imidazolium salts}

The synthesis of ferrocenyl (benz)imidazolium salts where the heterocycle is directly linked to ferrocene can be carried out by formation of the heterocyclic moiety from aminoferrocene. ${ }^{[8-10]}$ In our case, further selective introduction in the 2 position of the (dimethylaminomethyl) moiety, if feasible, could have been laborious. It was therefore decided to start the synthesis of the imidazolium salts from commercially available $\mathrm{N}, \mathrm{N}$ (dimethylaminomethyl)ferrocene. Using a modified procedure from Plenio et al. ${ }^{[11]}$ and Yucel et al. ${ }^{[12]}$, this reagent can easily be functionalised by lithiation in diethyl ether at room temperature followed by reaction of the lithiated species with iodine at $-78^{\circ} \mathrm{C}$. The 1-iodo-2-(dimethylaminomethyl)ferrocene 1 was obtained in $64 \%$ yield as a moderately stable oily solid.

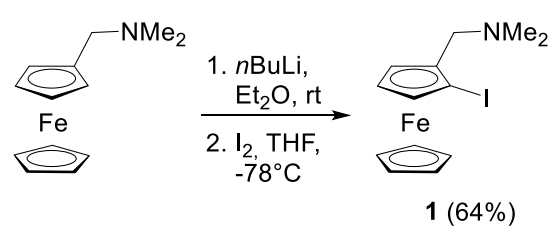

Scheme 1. Synthesis of 1-iodo-2-(dimethylaminomethyl)ferrocene 1.

The objective was then to introduce the imidazole ring by an Ullman-type coupling reaction. Bolm et al. used this strategy to generate compound $\mathbf{A}$ in $31 \%$ yield from iodoferrocene and imidazole with Cul as catalyst in DMSO (Scheme 2). ${ }^{[13]}$ Later, Nagarkar et al. optimised the synthesis using $\mathrm{Cu}(\mathrm{TMHD})_{2}$ as catalyst and $t \mathrm{BuOK}$ instead of $\mathrm{K}_{2} \mathrm{CO}_{3}$ and obtained the product in $46 \%$ yield. ${ }^{[14]}$ Finally, Jiang et al. prepared compound B in $51 \%$ yield, with $\mathrm{Cul}$ and 1,2-diaminocyclohexane in the presence of $\mathrm{Cs}_{2} \mathrm{CO}_{3}$ in dioxane. ${ }^{[15]}$ This method has the merit of being straightforward but gives the coupling products with poor to moderate yields. We thus studied various reaction parameters in 
order to optimise the yield of 1-(imidazol-1-yl)-2(dimethylaminomethyl)ferrocene, starting from conditions described by Cristau et al. ${ }^{[16]}$ and Cross et al. ${ }^{[17]}$ for the coupling of organic substrates.

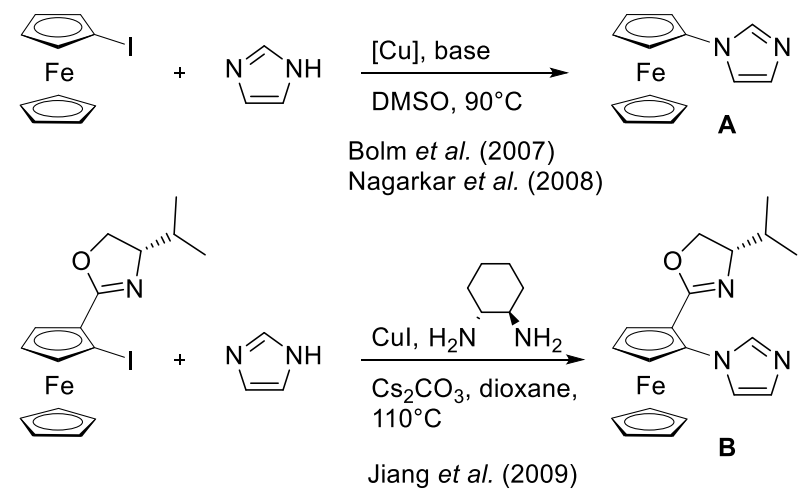

Scheme 2. Previous syntheses of imidazol-1-ylferrocene and derivatives by Ullman-type coupling.

1-lodo-2-(dimethylaminomethyl)ferrocene 1 was reacted with imidazole in the presence of $\mathrm{Cu}_{2} \mathrm{O}(5 \mathrm{~mol} \%)$, the tetradentate ligand $\mathrm{L}_{\mathbf{1}}(20 \mathrm{~mol} \%)$ and $\mathrm{Cs}_{2} \mathrm{CO}_{3}$ in refluxing acetonitrile (Scheme $3)$. After 5 days of heating, the coupling product 2 was obtained in only $30 \%$ yield. Buchwald et al. reported the use of PEG-3400 as a phase transfer reagent and observed that its addition accelerated the reaction, thanks to its propensity to increase the solubility of carbonates in organic media. ${ }^{[18 a]}$ They also used 4,7dimethoxy-1,10-phenanthroline instead of ligand $\mathbf{L}_{1}$, in combination with $\mathrm{Cu}_{2} \mathrm{O}$ and $\mathrm{Cs}_{2} \mathrm{CO}_{3}$ in nitrile solvents. ${ }^{[18 \mathrm{~b}]}$ PEG3400 was therefore added to the reaction mixture, in the presence of 4-methyl-1,10-phenanthroline $\left(\mathbf{L}_{2}\right)$, which allowed complete consumption of $\mathbf{1}$ in $24 \mathrm{~h}$ instead of 5 days. Several parameters were then changed, such as the nitrile solvent, the temperature, the ligand, the catalytic charge and finally the amount of substrate engaged in the reaction (Table 1).
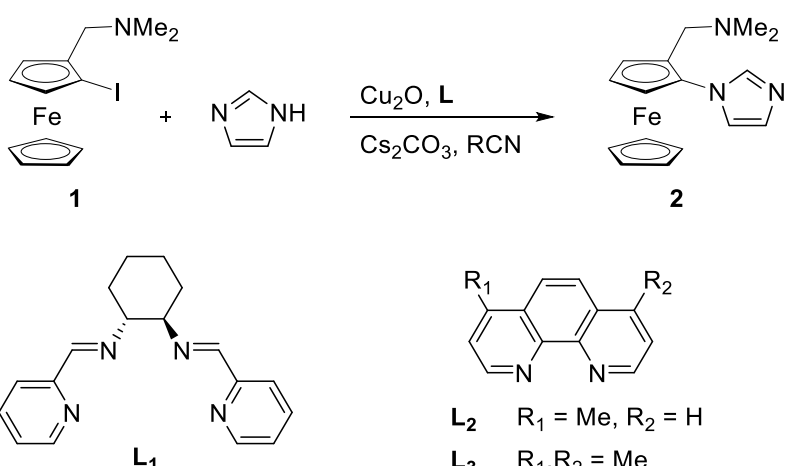

2

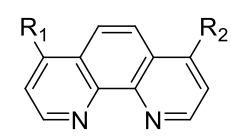

$\mathrm{L}_{2} \quad \mathrm{R}_{1}=\mathrm{Me}, \mathrm{R}_{2}=\mathrm{H}$

$\mathrm{L}_{3} \quad \mathrm{R}_{1}, \mathrm{R}_{2}=\mathrm{Me}$

Scheme 3. Synthesis of 2 via an Ullman-type coupling reaction.

Table 1. Optimisation of reaction parameters for the synthesis of 2 .

\begin{tabular}{llcccccc}
\hline Entry & $\begin{array}{l}\mathrm{n}(\mathbf{1}) \\
(\mathrm{mmol})\end{array}$ & $\begin{array}{l}{[\mathrm{Cu}]} \\
(\mathrm{mol} \%)\end{array}$ & $\begin{array}{l}\text { Ligand } \\
(\mathrm{mol} \%)\end{array}$ & $\begin{array}{l}\mathrm{T} \\
\left({ }^{\circ} \mathrm{C}\right)\end{array}$ & Solvent & $\begin{array}{l}\mathrm{t} \\
(\mathrm{h})\end{array}$ & $\begin{array}{l}\text { Yield } \\
(\%)\end{array}$ \\
\hline 1 & 2.71 & 5 & $\mathrm{~L}_{1}(20)$ & 80 & $\mathrm{CH}_{3} \mathrm{CN}$ & 120 & 31 \\
2 & 2.71 & 5 & $\mathrm{~L}_{2}(20)$ & 120 & $\mathrm{C}_{3} \mathrm{H}_{7} \mathrm{CN}$ & 16 & 48 \\
3 & 2.71 & 5 & $\mathrm{~L}_{2}(20)$ & 80 & $\mathrm{CH}_{3} \mathrm{CN}$ & 24 & 48 \\
4 & 2.71 & 10 & $\mathrm{~L}_{2}(30)$ & 120 & $\mathrm{C}_{3} \mathrm{H}_{7} \mathrm{CN}$ & 16 & 27 \\
5 & 2.71 & 10 & $\mathrm{~L}_{2}(30)$ & 80 & $\mathrm{CH}_{3} \mathrm{CN}$ & 24 & 25 \\
6 & 2.71 & 5 & $\mathrm{~L}_{3}(20)$ & 120 & $\mathrm{C}_{3} \mathrm{H}_{7} \mathrm{CN}$ & 16 & 47 \\
7 & 8.13 & 5 & $\mathrm{~L}_{2}(20)$ & 120 & $\mathrm{C}_{3} \mathrm{H}_{7} \mathrm{CN}$ & 16 & 31 \\
\hline
\end{tabular}

The use of butyronitrile at $120^{\circ} \mathrm{C}$ allowed the reaction to be complete in $16 \mathrm{~h}$ instead of $24 \mathrm{~h}$, however with no yield improvement. Surprisingly, increasing the catalytic charge from 5 mol\% to $10 \mathrm{~mol} \% \mathrm{Cu}$ led to lower yields. Finally, the use of more electron-rich 4,7-dimethyl-1,10-phenanthroline (entry 6) did not have any influence on the reaction outcome. The best yield of 1 (imidazol-1-yl)-2-(dimethylaminomethyl)ferrocene 2 (48\%, entry 3) was therefore obtained with $5 \mathrm{~mol} \% \mathrm{Cu}_{2} \mathrm{O}$ and $20 \mathrm{~mol} \%$ 4methyl-1,10-phenanthroline after $24 \mathrm{~h}$ in refluxing acetonitrile. Unfortunately, the yield of 2 dropped to $31 \%$ when we tried to scale-up the reaction (entry 7 ).

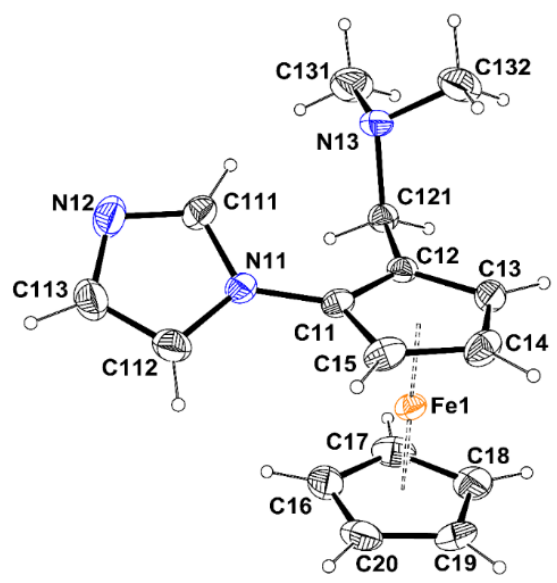

Figure 2. ORTEP representation of 1-(imidazol-1-yl)-2-(dimethylaminomethyl)ferrocene, rac-2. Ellipsoids are shown at the 50\% level. Selected bond lengths $(\AA)$ and angles $\left({ }^{\circ}\right)$ : $N(11)-C(111), 1.363(3) ; N(12)-C(111), 1.320(3) ; C(112)$ $\mathrm{C}(113), 1.360(4) ; \mathrm{N}(11)-\mathrm{C}(111)-\mathrm{N}(12), 112.1(3)$.

Compound 2 was fully characterised by usual analytical methods. Its ${ }^{1} \mathrm{H}$ NMR spectrum shows an AB system at $\delta$ ca. 3.3 with a $J_{H H}$ coupling constant of $13 \mathrm{~Hz}$, characteristic of diastereotopic methylene protons. X-ray quality orange crystals were obtained by slow evaporation of a concentrated solution of $\mathbf{2}$ in acetone (Figure 2). The X-ray structure of $\mathbf{2}$ was compared to 
that of (imidazol-1-yl)ferrocene ${ }^{[19]}$ : bond lengths and angles are similar in both structures and it is interesting to note that the imidazole and cyclopentandienyl rings are not coplanar.

Another interesting feature is the presence of a hydrogen bond between the nitrogen atom of the amino group (N13) and the hydrogen atom on the imidazole $\mathrm{C} 111$ atom (calculated value $\mathrm{H}(111) \cdots \mathrm{N}(13): 2.47 \AA)$.

Imidazolium salts were then prepared by reaction of $\mathbf{2}$ with alkyl halides. Two alkylating agents, i.e. methyl iodide and 2,4,6trimethylbenzyl bromide, were used so as to introduce substituents generating a different steric bulk. In order to alkylate selectively the imidazole moiety, the more reactive alkylamine had to be protected. The reaction of $\mathbf{2}$ with one equivalent of $\mathrm{BH}_{3} . \mathrm{THF}^{[20]}$ at various temperatures was not efficient since it only led to a mixture of the expected amine-borane complex and of the double adduct, along with some unreacted material. Selective protonation of the amino moiety was thus attempted. Treatment of 2 with one equivalent of $\mathrm{HCl}$ in $\mathrm{Et}_{2} \mathrm{O}$ afforded a yellow precipitate that was analysed by ${ }^{1} \mathrm{H}$ NMR. The spectrum showed very broad imidazole signals with no shift of the $\mathrm{C} 2$ proton to higher frequencies, which leads us to propose the existence of a rapid equilibrium between the expected ammonium form $\mathbf{3}$ and the imidazolium form (Scheme 4). The pale yellow solid was then taken up into $\mathrm{MeCN}$, an excess of alkylating agent was added and the mixture was heated at reflux during $24 \mathrm{~h}$. In the case of Mel, a dicationic compound (4), hardly soluble in organic solvents but much more so in water, was obtained. The addition of $\mathrm{Na}_{2} \mathrm{CO}_{3}$ allowed the deprotonation of $\mathbf{4}$ to produce the imidazolium salt $\mathbf{5}$ as an orange solid, soluble in dichloromethane. The formation of the imidazolium salt was confirmed by the presence of a singlet at $\delta 10.17$ in the ${ }^{1} \mathrm{H}$ NMR spectrum, characteristic of the acidic proton situated between the two nitrogen atoms.

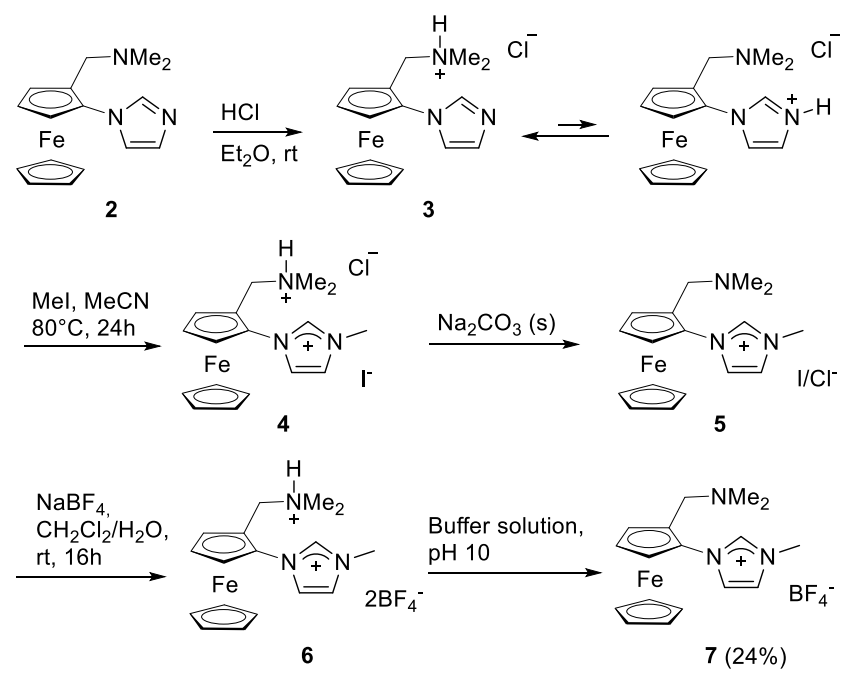

Scheme 4. Synthesis of imidazolium salt 7 .

Compound $\mathbf{5}$ proved rather unstable, even when stored at $20^{\circ} \mathrm{C}$ under an inert atmosphere. Therefore, it was submitted to a metathesis reaction to change the iodide/chloride anions with tetrafluoroborate. A solution of $\mathrm{NaBF}_{4}$ in water was thus added to a dichloromethane solution of $\mathbf{5}$ and the mixture was vigorously stirred at room temperature for $16 \mathrm{~h}$. Under these conditions, the amine is protonated again and the dicationic species 6 is transferred into the aqueous phase. The desired imidazolium salt 7 was regenerated by buffering of the aqueous solution to $\mathrm{pH} 10$ and extraction into dichloromethane. ${ }^{[21]}$ After work-up, 7 was obtained as a very hygroscopic yellow solid in $24 \%$ yield from 2 . The singlet corresponding to the acidic proton of the imidazolium moiety now appears at at $\delta 9.56$ in the ${ }^{1} \mathrm{H}$ NMR spectrum, compared to $\delta 10.17$ for $\mathbf{5}$, which corroborates the anion exchange. This value is in accord with data found in the literature for analogous compounds. ${ }^{[22]}$ The low yield of 7 may be partially explained by the existence of an electrostatic repulsion between the two positive charges in intermediates $\mathbf{4}$ and $\mathbf{6}$, which does not favour their formation.

The synthesis of the imidazolium salt bearing a bulkier $(2,4,6$ trimethylphenyl)methyl substituent was attempted according to a similar procedure. However, the expected imidazolium salt was not obtained. Surprisingly, we observed instead the clean formation of doubly alkylated salt $\mathbf{8}$ along with some unreacted compound 2, whereas the expected monoalkylated species was not detected. The introduction of two mesityl substituents makes the ammmonium/imidazolium salt rather lipophilic. Hence, contrary to 7 , this compound remains in the organic phase during the metathesis step despite the presence of two positive charges. The ammonium/imidazolium salt $\mathbf{8}$ was obtained as a yellow solid in $27 \%$ yield from 2 (Erreur ! Source du renvoi introuvable.5).

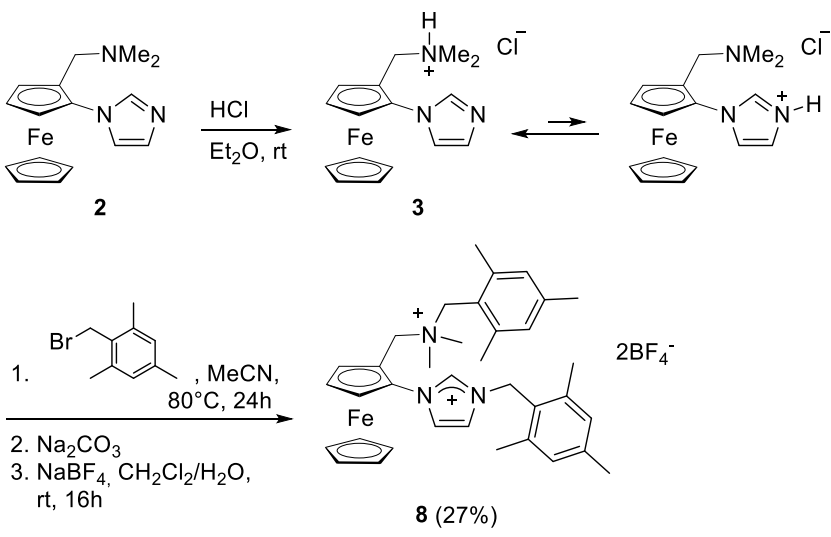

Scheme 5. Synthesis of ammonium/imidazolium salt 8 .

The product was analysed by ${ }^{1} \mathrm{H}$ and ${ }^{13} \mathrm{C}$ NMR: the acidic proton of the imidazolium moiety was found at $\delta 8.77$ in the ${ }^{1} \mathrm{H}$ NMR spectrum. The generation of the doubly alkylated product was confirmed by the presence of two AB systems at $\delta$ 5.51-5.46 and 4.40-4.35 integrating for two protons each, in addition to that of the two methylene protons adjacent to ferrocene (at $\delta 4.76$ and 4.61). The two methyl substituents of the amino group appeared in the ${ }^{1} \mathrm{H}$ NMR spectrum as two singlets integrating for 3 protons each, confirming a stable tetrahedral geometry around the nitrogen atom as found in ammoniums. The same behaviour was 
observed in the ${ }^{13} \mathrm{C}$ NMR spectrum, with the observation of two signals for the methyl carbon nuclei at $\delta 47.95$ and 47.76 . Finally, 18 protons were found between $\delta 2.31$ and 2.29 , corresponding to the methyl protons of the mesitylene moieties. This reactivity was only and consistently observed with (2,4,6trimethylphenyl)methyl bromide, whereas imidazolium salt 7 was the only compound identified in the reaction mixture when methyl iodide was used. The reasons for this unusual reactivity cannot simply be accounted for on grounds of differences in kinetics or pKa values. Therefore, a more thorough experimental study shall be conducted in a future work in order to evaluate the influence of each reaction parameter (i.e. solvent, concentration of reagent), and more particularly the nature of the halogen with the use of (2,4,6-trimethylphenyl)methyl iodide.

\section{Synthesis of palladium complexes}

The generation of palladium complexes was first attempted by preparation of intermediate silver complexes. However, the addition of $\mathrm{Ag}_{2} \mathrm{O}$ to the imidazolium salt $\mathbf{7}$ in dichloromethane led to the formation of an intractable black precipitate, probably containing metallic silver.

In order to check the feasibility of the reaction, the free carbene was prepared by addition of a solution of potassium bis(trimethylsilyl)amide to a THF solution of imidazolium salt 7 at room temperature (Scheme 6). The initial yellow-orange solution became bright red during the addition of the base. After 20 minutes, the solvent was evaporated in vacuo and the solid analysed by ${ }^{1} \mathrm{H}$ and ${ }^{13} \mathrm{C}$ NMR in $\mathrm{C}_{6} \mathrm{D}_{6}$. The ${ }^{1} \mathrm{H}$ NMR spectrum showed the disappearance of the imidazolium acidic proton at $\delta$ 9.56, giving the first indication for the formation of the free carbene. The ${ }^{13} \mathrm{C}$ NMR spectrum displays a signal at $\delta 218.56$, which corresponds to the carbenic carbon. To our knowledge, this is the second example reported in the literature of an isolated and characterised imidazol-2-ylidene directly linked to ferrocene. The only other example was reported by Togni et al. in 2005 and showed a signal at $\delta 216.10$ in the ${ }^{13} \mathrm{C}$ NMR spectrum for the carbenic carbon nucleus. [9]

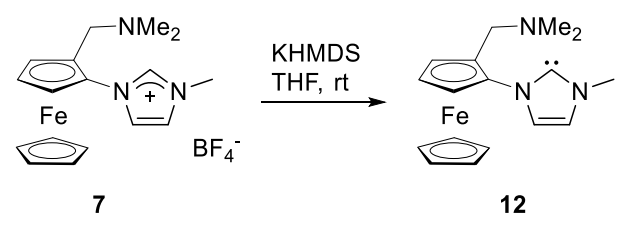

Scheme 6. Generation of the free carbene 12.

The free carbene 12 was then slowly added at room temperature to a THF solution of $\left[\mathrm{PdCl}_{2}(\mathrm{MeCN})_{2}\right]$. After $16 \mathrm{~h}$ at this temperature, a black suspension was observed in a pale yellow solution. Unfortunately, the ${ }^{1} \mathrm{H}$ NMR revealed that the solution only contained the palladium precursor whereas the ligand decomposed into an intractable black solid. The same reaction conducted at $0^{\circ} \mathrm{C}$ led to the same result. We finally attempted to generate the palladium complex by in-situ formation of the carbene, in the presence of the palladium salt. Following a procedure reported by Ying et al., ${ }^{[23]}$ the imidazolium salt 7 was added to a solution of $\left[\mathrm{PdCl}_{2}(\mathrm{MeCN})_{2}\right]$ and $\mathrm{K}_{2} \mathrm{CO}_{3}$ in acetonitrile and the mixture was heated at reflux for $1 \mathrm{~h} .{ }^{1} \mathrm{H}$ NMR analysis of the dark brown residue showed a mixture of starting imidazolium salt 7 and another unidentified ferrocenyl compound. When tBuOK was used in place of $\mathrm{K}_{2} \mathrm{CO}_{3}$ and the reaction mixture heated at $50^{\circ} \mathrm{C}$ for $16 \mathrm{~h}$, the formation of the expected palladium complex 13 was observed (Scheme 7).

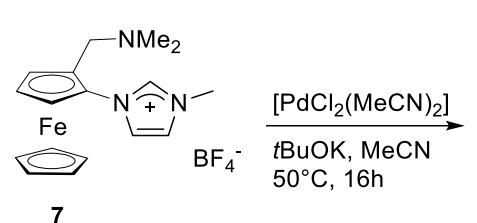

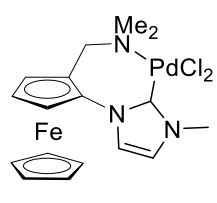

$13(29 \%)$
Scheme 7. Synthesis of neutral palladium(II) complex 13

First, the ${ }^{1} \mathrm{H}$ NMR spectrum showed the disappearance of the signal corresponding to the acidic proton of imidazolium. The methyl protons of the amino moiety, visible as one singlet at $\delta$ 2.20 integrating for 6 protons in the case of imidazolium salt 7 , appear now as two singlets at $\delta 2.96$ and 2.84 , each integrating for 3 protons. The ${ }^{13} \mathrm{C}$ NMR spectrum of $\mathbf{1 3}$ clearly indicates the presence of a signal at $\delta 154.23$, typical of carbenic carbon nuclei in $\mathrm{Pd}(\mathrm{II})-\mathrm{NHC}$ complexes. As a reference, the corresponding signal for a palladium(II) complex bearing a ferrocenyl NHC ligand, reported by Togni et al., appears at $\delta 151.10 .{ }^{[9]}$ The palladium complex has also been characterised by high resolution mass spectrometry (ESI): the molecular peak corresponds to complex 13 after the loss of $\mathrm{HCl}_{2}$. This type of rearrangement has already been observed by Douthwaite et al. for similar complexes. ${ }^{[24]}$ The absence of an X-ray structure makes it difficult to confirm the coordination of the amine on the palladium centre. However, in a similar case, Elsevier et al. justified the coordination of the amine on palladium by the shift of the ${ }^{1} \mathrm{H}$ NMR signal of the two methyl groups to higher frequencies. ${ }^{[25]}$ Their hypothesis has been confirmed by the resolution of the structure by X-ray crystallography. With this data in hand we propose the likely structure of our palladium complex $\mathbf{1 3}$ as shown in scheme 8 . Airstable complex 13 has been obtained as a yellow solid in $29 \%$ yield.

The same procedure was applied to generate cationic palladium complex 14, bearing a bulkier $\mathrm{CH}_{2}$ Mes substituent on the NHC moiety, from the ammonium/imidazolium salt 8 (Scheme 8). Complex 14 was obtained as a yellow solid in $32 \%$ yield. Similarly to 13 , the ${ }^{1} \mathrm{H}$ NMR spectrum of this new compound does not show any signal for the acidic proton of imidazolium salt $\mathbf{8}$. The two protons of the $A B$ system neighbouring the imidazol-2ylidene unit split upon coordination of the ligand on palladium and the chemical shift changes from $\delta 5.51$ and 5.46 in 8 to $\delta 5.86$ and 5.52 in 14. The protons of the $A B$ system situated between the positively charged nitrogen atom and the mesityl moiety also split but do not shift, from $\delta 4.40$ and 4.35 in 8 to $\delta 4.49$ and 4.29 in 14 Finally, the ${ }^{13} \mathrm{C}$ NMR spectrum shows a signal at $\delta 149.97$ for the carbenic carbon. By comparison with previously reported examples of palladium-NHC complexes, ${ }^{[26]}$ we propose the 
structure represented in Scheme 9. Indeed, the chemical shift observed for the carbenic carbon is typical of a palladium centre bearing one $\mathrm{NHC}$ ligand, the coordination sphere being completed by a molecule of acetonitrile. Corresponding ${ }^{13} \mathrm{C}$ NMR chemical shifts for bis-NHC palladium complexes are usually observed at higher frequencies. ${ }^{[27]}$ Finally, analysis by high resolution mass spectrometry $(E S I)$ gives a peak for $\mathrm{m} / \mathrm{z}=546$ corresponding to complex 14 after the loss of $\mathrm{HCl}_{2}^{-}$, a $(2,4,6-$ trimethylphenyl)methyl fragment and $\mathrm{MeCN}$.

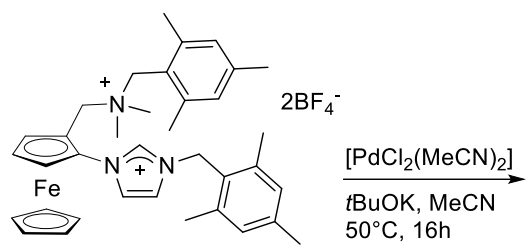

8

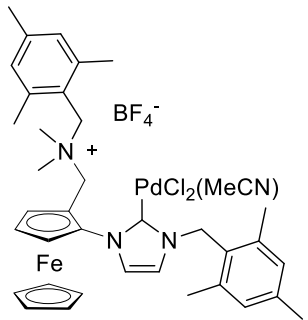

$14(32 \%)$
Scheme 8. Synthesis of cationic palladium(II) complex 14

\section{Conclusions}

The synthesis of two new ferrocenylimidazolium salts is reported in five steps from commercially available (dimethylaminomethyl) ferrocene. Whereas an amine/imidazolium salt (7) was obtained by reaction of protonated 1-(imidazol-1-yl)-2(dimethylaminomethyl)ferrocene $\mathbf{3}$ with methyl iodide, the unexpected dialkylated ammonium/imidazolium dicationic species 8 was isolated after reaction of (2,4,6trimethylphenyl)methyl bromide with intermediate 3. A free carbene was generated from the imidazolium salt 7 , isolated and characterised by ${ }^{1} \mathrm{H}$ and ${ }^{13} \mathrm{C}$ NMR. Palladium(II)-NHC complexes were finally prepared by in-situ deprotonation of both imidazolium salts in the presence of a palladium precursor. In the case of complex 13, amine coordination to the palladium centre is proposed by analogy with existing palladium(II)-NHC/amine complexes. The structure of complex 14, prepared from the ammonium/imidazolium salt $\mathbf{8}$, is believed to be cationic with a monodentate $\mathrm{NHC}$ and a dangling ammonium substituent. These new proligands, which present a planar chirality, were prepared as racemic mixtures. The synthesis of enantiopure imidazolium salts and of the corresponding palladium(II) complexes is underway in our laboratories, as well as the evaluation of the latter in catalysis. The results of these investigations will be reported in due course.

\section{Experimental Section}

General considerations. All manipulations were performed under an inert atmosphere of dry argon by using vacuum line and Schlenk tube techniques. Solvents for syntheses were dried and degassed by standard methods before use. 1D- and 2D-NMR spectra were recorded on a Bruker
AV400 spectrometer. ${ }^{1} \mathrm{H}$ and ${ }^{13} \mathrm{C}$ chemicals shifts $(\delta)$ are given in ppm (the residual peak of deuterated solvent was used as reference). Peaks are labeled as singlet (s), doublet (d), triplet (t), multiplet $(\mathrm{m})$ and broad (br). The proton and carbon assignments were performed by COSY, HSQC, ${ }^{1} \mathrm{H}-{ }^{13} \mathrm{C}$ HMBC experiments. MS spectra were performed by the mass spectrometry service of the Paul Sabatier University. Commercial chemicals were from Acros, Aldrich, Alfa Aesar, or Fluka and used as received. The buffer solution $(\mathrm{pH} 10)$ used for the synthesis of 7 was realised by mixing $100 \mathrm{~mL}$ of a $0.05 \mathrm{M}$ aqueous $\mathrm{NaHCO}_{3}$ solution and 21.4 $\mathrm{mL}$ of a $0.1 \mathrm{M}$ aqueous $\mathrm{NaOH}$ solution. Abbreviations: $\mathrm{Cp}_{\mathrm{A}}$ : cyclopentadienyl ring with $-\mathrm{CH}_{2} \mathrm{NMe}_{2}$ and $\mathrm{NHC}$ substituents; $\mathrm{Cp}_{\mathrm{B}}$ : unsubstituted cyclopentadienyl ring; Fc: ferrocenyl; Im: imidazolyl; Mes: mesityl. Cq: quaternary carbon.

\section{Syntheses}

1-iodo-2-(dimethylaminomethyl)ferrocene (1) In a dry Schlenk tube, (dimethylaminomethyl)ferrocene $(19.65 \mathrm{~g}, 80.9 \mathrm{mmol})$ was dissolved in dry $\mathrm{Et}_{2} \mathrm{O}(300 \mathrm{~mL}) . n$-Butyllithium $(71 \mathrm{~mL}, 114 \mathrm{mmol}, 1.6 \mathrm{M}$ in hexanes) was slowly added at room temperature and the mixture was stirred for $4 \mathrm{~h}$ protected from light. After cooling down to $-78^{\circ} \mathrm{C}$, a solution of $\mathrm{I}_{2}(28.0 \mathrm{~g}$, $110 \mathrm{mmol})$ in dry THF $(75 \mathrm{~mL})$ was added dropwise to the reaction mixture. The temperature was allowed to warm to room temperature over $1 \mathrm{~h}$ and stirred at this temperature for $15 \mathrm{~min}$. A $10 \%$ aq. $\mathrm{Na}_{2} \mathrm{~S}_{2} \mathrm{O}_{3}$ solution (500 $\mathrm{mL}$ ) was added, the phases were separated and the aqueous phase was extracted with MTBE until the organic extracts were colourless. The organic phases were combined, dried $\left(\mathrm{MgSO}_{4}\right)$, filtered and the solvents were evaporated in vacuo. The residue was first purified by column chromatography on basic alumina (eluent: $\mathrm{CH}_{2} \mathrm{Cl}_{2}$ ), then on silicagel (eluent: petroleum ether/AcOEt/NEt $3: 8 / 2 / 1$ ) to afford a red oil that solidifies partly upon standing (19.0 g, 64\% yield). ${ }^{1} \mathrm{H} \mathrm{NMR}\left(400 \mathrm{MHz}, \mathrm{CDCl}_{3}, 298\right.$ K) $\delta 4.31\left(1 \mathrm{H}, \mathrm{s}\right.$ br., $\mathrm{CH} \mathrm{Cp}$ ), $4.16\left(1 \mathrm{H}, \mathrm{s}\right.$ br., $\mathrm{CH} \mathrm{Cp}$ A), $4.08\left(1 \mathrm{H}, \mathrm{t}, J_{\mathrm{HH}}=\right.$ $\left.2.5 \mathrm{~Hz}, \mathrm{CH} \mathrm{Cp}_{\mathrm{A}}\right), 3.98\left(5 \mathrm{H}, \mathrm{s}, \mathrm{CH} \mathrm{Cp}_{\mathrm{B}}\right), 3.24\left(2 \mathrm{H}, \mathrm{s}, \mathrm{CH}_{2}\right), 2.12(6 \mathrm{H}, \mathrm{s}$, $\left.\mathrm{CH}_{3}\right)$.

1-(imidazol-1-yl)-2-(dimethylaminomethyl)ferrocene (2) Compound 1 $(1.0 \mathrm{~g}, 2.7 \mathrm{mmol})$, imidazole $(220 \mathrm{mg}, 3.23 \mathrm{mmol}), \mathrm{Cs}_{2} \mathrm{CO}_{3}(1.7 \mathrm{~g}, 5.28$ $\mathrm{mmol}), \mathrm{Cu}_{2} \mathrm{O}$ (20 mg, $\left.0.138 \mathrm{mmol}\right)$, 4-methyl-1,10-phenanthroline (105 mg, $0.54 \mathrm{mmol})$, PEG-3400 (550 mg) and MeCN (1 mL) were placed in a dry Schlenk tube and heated to $80^{\circ} \mathrm{C}$ for $24 \mathrm{~h}$. After cooling to room temperature, the black paste was extracted with $\mathrm{CH}_{2} \mathrm{Cl}_{2}$ until the extracts were colourless. The organic extracts were filtered through Celite $\AA$ and combined, washed with water and with a $10 \%$ aq. $\mathrm{Na}_{2} \mathrm{~S}_{2} \mathrm{O}_{3}$ solution, dried $\left(\mathrm{MgSO}_{4}\right)$, filtered and evaporated to dryness in vacuo. The residue was purified by column chromatography on silicagel (eluent: petroleum ether/AcOEt: $8 / 2$ with $10 \% \mathrm{NEt}_{3}$ ). After evaporation of the solvents, the product was dissolved in water and the red solution was extracted with pentane. The organic extracts were combined, washed with water, dried $\left(\mathrm{MgSO}_{4}\right)$, filtered and evaporated to dryness in vacuo to afford 2 as an orange crystalline solid (400 mg, $48 \%$ yield). ${ }^{1} \mathrm{H} \mathrm{NMR}\left(400 \mathrm{MHz}, \mathrm{CDCl}_{3}\right.$, 298K) $\delta 8.03(1 \mathrm{H}, \mathrm{s}, \mathrm{N}-\mathrm{CH}-\mathrm{N}), 7.35(1 \mathrm{H}, \mathrm{s}, \mathrm{CH}=\mathrm{CH}), 7.09(1 \mathrm{H}, \mathrm{s}, \mathrm{CH}=\mathrm{CH})$, $4.44\left(1 \mathrm{H}, \mathrm{t}, \mathrm{J}_{\mathrm{HH}}=2 \mathrm{~Hz}, \mathrm{CH} \mathrm{Cp}_{\mathrm{A}}\right), 4.24\left(1 \mathrm{H}, \mathrm{t}, \mathrm{J}_{\mathrm{HH}}=2.4 \mathrm{~Hz} \mathrm{CH} \mathrm{Cp}_{\mathrm{A}}\right), 4.20$ $\left(5 \mathrm{H}, \mathrm{s}, \mathrm{CH} \mathrm{Cp}_{\mathrm{B}}\right), 4.17\left(1 \mathrm{H}, \mathrm{t}, \mathrm{J}_{\mathrm{HH}}=2.4 \mathrm{~Hz}, \mathrm{CH} \mathrm{Cp}\right), 3.46\left(1 \mathrm{H}, \mathrm{AB}\right.$ syst $J_{\mathrm{HH}}$ $\left.=13 \mathrm{~Hz}, \mathrm{CH}_{2}\right), 3.14\left(1 \mathrm{H}, \mathrm{AB}\right.$ syst $\left.J_{\mathrm{HH}}=13 \mathrm{~Hz}, \mathrm{CH}_{2}\right), 2.13\left(6 \mathrm{H}, \mathrm{s}, 2 \mathrm{CH}_{3}\right)$. ${ }^{13} \mathrm{C}$ NMR (100 MHz, CDCl $\left.3,298 \mathrm{~K}\right) \delta 139.21$ (Im N-ChH-N), 128.88 (Im $\underline{\mathrm{CH}}=\mathrm{CH}), 121.70(\mathrm{Im} \mathrm{CH}=\underline{\mathrm{CH}}), 94.61\left(\mathrm{C}^{\mathrm{q}} \mathrm{Cp} A\right), 78.80\left(\mathrm{C}^{q} \mathrm{Cp}\right), 70.23(\mathrm{Cp})$,

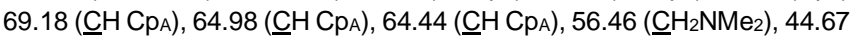
$\left(2 \mathrm{CH}_{3}\right) . \mathrm{MS}(\mathrm{ESI}): \mathrm{m} / \mathrm{z} 310\left[\mathrm{M}+\mathrm{H}^{+}\right](75) ; 265\left[\mathrm{M}-\mathrm{NH}^{+} \mathrm{Me}_{2}\right](100)$. HR-MS (ES+) calcd for $\mathrm{C}_{16} \mathrm{H}_{20} \mathrm{~N}_{3} \mathrm{Fe} 310.1881$, found 310.1008 .

Amine/imidazolium tetrafluoroborate salt (7) In a dry Schlenk tube, $\mathrm{HCl}$ (515 $\mu \mathrm{L}, 0.515 \mathrm{mmol}, 1 \mathrm{~mol} . \mathrm{L}^{-1}$ in $\mathrm{Et}_{2} \mathrm{O}$ ) was slowly added at room temperature to a solution of compound 2 (159 $\mathrm{mg}, 0.515 \mathrm{mmol}$ ) in $\mathrm{Et}_{2} \mathrm{O}$ $(20 \mathrm{~mL})$. Following the appearance of a yellow precipitate, the mixture was 
stirred for $10 \mathrm{~min}$ at room temperature. The solvent was evaporated in vacuo and the residue taken up into $\mathrm{MeCN}(20 \mathrm{~mL})$, then $\mathrm{Mel}(318 \mathrm{~mL}$, $5.15 \mathrm{mmol}$ ) was added with stirring. The mixture was heated at $80^{\circ} \mathrm{C}$ for $24 \mathrm{~h}$. The solvent was evaporated in vacuo and the residue taken up into $\mathrm{CH}_{2} \mathrm{Cl}_{2}$. Solid $\mathrm{Na}_{2} \mathrm{CO}_{3}$ was added and the solution was stirred at room temperature for $20 \mathrm{~min}$, then filtered and concentrated in vacuo. $\mathrm{NaBF}_{4}(10$ eq.) and water $\left(10 \mathrm{~mL}\right.$ ) were added to the $\mathrm{CH}_{2} \mathrm{Cl}_{2}$ solution and the mixture was vigorously stirred at room temperature for $16 \mathrm{~h}$. The phases were separated, the aqueous phase was buffered to $\mathrm{pH} 10$ and then extracted with $\mathrm{CH}_{2} \mathrm{Cl}_{2}$. The organic phases were combined, dried $\left(\mathrm{MgSO}_{4}\right)$, filtered and concentrated in vacuo. The residue was purified by precipitation by the addition of excess MTBE to a concentrated solution of $\mathrm{CH}_{2} \mathrm{Cl}_{2}$. The imidazolium salt 7 was obtained as a very hygroscopic yellow solid ( $50 \mathrm{mg}$, $24 \%$ yield). ${ }^{1} \mathrm{H}$ NMR (400 MHz, $\left.\mathrm{CDCl}_{3}, 298 \mathrm{~K}\right) \delta 9.56(1 \mathrm{H}, \mathrm{s}, \mathrm{NCHN}), 8.04$ $\left(1 \mathrm{H}\right.$, pseudo $\left.\mathrm{t}, \mathrm{J}_{\mathrm{HH}}=1.6 \mathrm{~Hz}, \mathrm{CH}=\mathrm{CH}\right), 7.51\left(1 \mathrm{H}\right.$, pseudo $\mathrm{t}, J_{\mathrm{HH}}=1.6 \mathrm{~Hz}$, $\mathrm{CH}=\mathrm{CH}), 4.77\left(1 \mathrm{H}, \mathrm{t}, \mathrm{J}_{\mathrm{HH}}=2 \mathrm{~Hz}, \mathrm{CH} \mathrm{Cp}_{\mathrm{A}}\right), 4.29(5 \mathrm{H}, \mathrm{s}, \mathrm{CpB}), 4.25(1 \mathrm{H}, \mathrm{s}$, $\left.\mathrm{CH} \mathrm{Cp}_{\mathrm{A}}\right), 4.24\left(1 \mathrm{H}, \mathrm{s}, \mathrm{CH} \mathrm{Cp}_{\mathrm{A}}\right), 4.06\left(3 \mathrm{H}, \mathrm{s}, \mathrm{Im}^{+} \mathrm{CH}_{3}\right), 3.73(1 \mathrm{H}, \mathrm{AB}$ syst., $\left.J_{H H}=13.2 \mathrm{~Hz}, \mathrm{CH}_{2}\right), 2.95\left(1 \mathrm{H}, \mathrm{AB}\right.$ syst., $\left.J_{\mathrm{HH}}=13.2 \mathrm{~Hz}, \mathrm{CH}_{2}\right), 2.19(6 \mathrm{H}, \mathrm{s}$, $\left.\mathrm{N}\left(\mathrm{CH}_{3}\right)_{2}\right) .{ }^{13} \mathrm{C}\left\{{ }^{1} \mathrm{H}\right\} \mathrm{NMR}\left(100 \mathrm{MHz}, \mathrm{CDCl}_{3}, 298 \mathrm{~K}\right) \delta 137.39(\mathrm{~N}-\underline{\mathrm{C}} \mathrm{H}-\mathrm{N})$, $124.24(\underline{\mathrm{CH}}=\mathrm{CH}), 123.95(\mathrm{CH}=\underline{\mathrm{CH}}), 92.84\left(\mathrm{C}^{\mathrm{q}} \mathrm{CpA}\right), 78.71\left(\mathrm{C}^{\mathrm{q}} \mathrm{CpA}\right), 71.20$

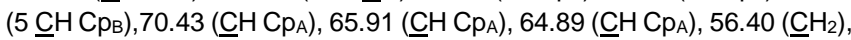
$44.52\left(\mathrm{~N}\left(\underline{\mathrm{CH}}_{3}\right)_{2}\right), 36.78\left(\mathrm{Im}^{+} \underline{\mathrm{C}} \mathrm{H}_{3}\right)$. MS (ESI) $\mathrm{m} / \mathrm{z} 324\left[\mathrm{M}^{+}\right]$(100). HR-MS (ES+) calcd for $\mathrm{C}_{17} \mathrm{H}_{22} \mathrm{~N}_{3} \mathrm{Fe} 324.1163$, found 324.1159 .

Ammonium/imidazolium bis(tetrafluoroborate) salt (8) In a dry Schlenk tube, $\mathrm{HCl}\left(275 \mu \mathrm{L}, 0.275 \mathrm{mmol}, 1 \mathrm{~mol}^{-1} \mathrm{~L}^{-1}\right.$ in $\left.\mathrm{Et}_{2} \mathrm{O}\right)$ was slowly added at room temperature to a solution of compound 2 (85 $\mathrm{mg}, 0.275 \mathrm{mmol}$ ) in $\mathrm{Et}_{2} \mathrm{O}(10 \mathrm{~mL})$. Following the appearance of a yellow precipitate, the mixture was stirred for $10 \mathrm{~min}$ at room temperature. The solvent was evaporated in vacuo and the residue taken up into $\mathrm{MeCN}(10 \mathrm{~mL})$, then 2,4,6trimethylbenzyl bromide $(293 \mathrm{mg}, 1.37 \mathrm{mmol}$ ) was added with stirring. The mixture was heated at $80^{\circ} \mathrm{C}$ for $24 \mathrm{~h}$. The solvent was evaporated in vacuo and the residue taken up into $\mathrm{CH}_{2} \mathrm{Cl}_{2}$. Solid $\mathrm{Na}_{2} \mathrm{CO}_{3}$ was added and the solution was stirred at room temperature for $20 \mathrm{~min}$, then filtered and concentrated in vacuo. $\mathrm{NaBF}_{4}$ (10 eq.) and water $(10 \mathrm{~mL})$ were added to the $\mathrm{CH}_{2} \mathrm{Cl}_{2}$ solution and the mixture was vigorously stirred at room temperature for $16 \mathrm{~h}$. The phases were separated, the organic phase was dried $\left(\mathrm{MgSO}_{4}\right)$, filtered and concentrated in vacuo. The residue was purified by precipitation, by addition of excess MTBE to a concentrated solution of $\mathrm{CH}_{2} \mathrm{Cl}_{2}$. The imidazolium salt 8 was obtained as a very hygroscopic yellow solid (55 mg, $27 \%$ yield). ${ }^{1} \mathrm{H}$ NMR $\left(400 \mathrm{MHz}, \mathrm{CD}_{3} \mathrm{CN}\right.$, 298K) $\delta 8.78(1 \mathrm{H}, \mathrm{s}, \mathrm{NCHN}), 7.73(1 \mathrm{H}, \mathrm{s}, \mathrm{CH}=\mathrm{CH}), 7.20(1 \mathrm{H}, \mathrm{s}, \mathrm{CH}=\mathrm{CH})$, 7.05 (1H, s, CH Mes), 7.04 (1H, s, CH Mes), 7.02 (2H, s, CH Mes), 5.51 $\left(1 \mathrm{H}, \mathrm{AB}\right.$ syst. $\left.{ }^{2} \mathrm{JHH}_{\mathrm{H}}=15 \mathrm{~Hz}, \mathrm{Im}^{+} \mathrm{CH}_{2} \mathrm{Mes}\right), 5.46\left(1 \mathrm{H}, \mathrm{AB}\right.$ syst. ${ }^{2} \mathrm{JHH}_{\mathrm{HH}}=15 \mathrm{~Hz}$, Im $\left.{ }^{+} \mathrm{CH}_{2} \mathrm{Mes}\right), 5.00(1 \mathrm{H}, \mathrm{s}, \mathrm{CH} \mathrm{Cp} A), 4.87(1 \mathrm{H}, \mathrm{s}, \mathrm{CH} \mathrm{CpA}), 4.76(1 \mathrm{H}, \mathrm{AB}$ syst. $\left.{ }^{2} J_{\mathrm{HH}}=14 \mathrm{~Hz}, \mathrm{FCCH}_{2} \mathrm{~N}^{+}\right), 4.75\left(1 \mathrm{H}, \mathrm{s}, \mathrm{CH} \mathrm{Cp}_{\mathrm{A}}\right), 4.61(1 \mathrm{H}$, AB syst. $\left.{ }^{2} \mathrm{~J}_{\mathrm{HH}}=14 \mathrm{~Hz}, \mathrm{FCCH}_{2} \mathrm{~N}^{+}\right), 4.56(5 \mathrm{H}, \mathrm{s}, \mathrm{CH} \mathrm{Cp}), 4.40\left(1 \mathrm{H}, \mathrm{AB}\right.$ syst., ${ }^{2} \mathrm{~J}_{\mathrm{HH}}=$ $\left.14 \mathrm{~Hz}, \mathrm{~N}^{+} \mathrm{CH}_{2} \mathrm{Mes}\right), 4.35\left(1 \mathrm{H}, \mathrm{AB}\right.$ syst., $\left.{ }^{2} \mathrm{JHH}_{\mathrm{HH}} 14 \mathrm{~Hz}, \mathrm{~N}^{+} \mathrm{CH}_{2} \mathrm{Mes}\right), 2.64(3 \mathrm{H}$, s, $\left.\mathrm{N}^{+} \mathrm{CH}_{3}\right), 2.44\left(3 \mathrm{H}, \mathrm{s}, \mathrm{N}^{+} \mathrm{CH}_{3}\right), 2.31\left(9 \mathrm{H}, \mathrm{m}, \mathrm{CH}_{3} \mathrm{Mes}\right), 2.29(9 \mathrm{H}, \mathrm{s}$, $\mathrm{CH}_{3}$ Mes). ${ }^{13} \mathrm{C}$ NMR (100 MHz, CD 3 CN, 298K) $\delta 140.73$ (2 Cq Mes), 140.64

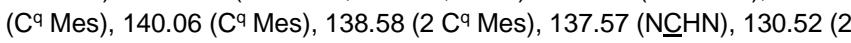
$\underline{\mathrm{C}} \mathrm{H}$ Mes), 129.72 (2 $\underline{\mathrm{CH}}$ Mes), $126.00(\underline{\mathrm{CH}}=\mathrm{CH}), 125.41$ ( $\left.{ }^{q} \mathrm{Mes}\right), 122.65$ $(\mathrm{CH}=\underline{\mathrm{C}} \mathrm{H}), 121.51$ ( $\left.\mathrm{C}^{\mathrm{q}} \mathrm{Mes}\right), 94.80$ ( $\left.\mathrm{C}^{\mathrm{q}} \mathrm{CpA}\right), 73.01$ (므 CpA), 72.01 (5 $\underline{\mathrm{CH}}$ $\left.\mathrm{Cp}_{\mathrm{B}}\right), 70.09\left(\underline{\mathrm{CH}} \mathrm{Cp}\right.$ A), $69.41\left(\underline{\mathrm{C}} \mathrm{H} \mathrm{Cp} \mathrm{p}_{\mathrm{A}}\right), 67.83\left(\mathrm{Cq} \underline{\mathrm{Cp}}_{\mathrm{A}}\right), 62.83\left(\mathrm{Fc}_{\mathrm{C}} \mathrm{H}_{2} \underline{\mathrm{N}}^{+}\right)$, $61.47\left(\mathrm{~N}^{+} \underline{\mathrm{C}} \mathrm{H}_{2} \mathrm{Mes}\right), 48.12\left(\mathrm{Im}^{+} \underline{\mathrm{C}} \mathrm{H}_{2} \mathrm{Mes}\right), 47.95\left(\underline{\mathrm{C}} \mathrm{H}_{3} \mathrm{~N}^{+}\right), 47.76\left(\underline{\mathrm{C}} \mathrm{H}_{3} \mathrm{~N}^{+}\right)$, 20.57 (2 $\underline{\mathrm{CH}}_{3} \mathrm{Mes}$ ), 20.14 ( $\underline{\mathrm{CH}}_{3} \mathrm{Mes}$ ), 20.02 ( $\left.\underline{\mathrm{CH}}_{3} \mathrm{Mes}\right), 18.88$ (2 $\left.\mathrm{CH}_{3} \mathrm{Mes}\right)$. MS (ESI) $m / z 442\left[\mathrm{M}^{2+}-\left(\mathrm{C}_{10} \mathrm{H}_{13}\right)^{+}\right](100), 397\left[\mathrm{M}^{2+}-\left(\mathrm{NHMe}_{2} \mathrm{C}_{10} \mathrm{H}_{13}\right)^{+}\right](28)$, $133\left[\mathrm{C}_{10} \mathrm{H}_{13}\right]^{+}(30)$. HR-MS (ES+) calcd for $\mathrm{C}_{26} \mathrm{H}_{32} \mathrm{~N}_{3} \mathrm{Fe} 442.1992$, found 442.1984

Amine/N-heterocyclic carbene (12) In a dry Schlenk tube, imidazolium salt 7 (71 mg, $0.173 \mathrm{mmol})$ was dissolved in dry THF (4.3 mL). KHMDS (360 $\mu \mathrm{L}, 0.181 \mathrm{mmol}, 0.5 \mathrm{~mol} . \mathrm{L}^{-1}$ in toluene) was added dropwise at room temperature and the solution was stirred for $20 \mathrm{~min}$. The solvents were evaporated in vacuo to afford carbene 12 as a bright red solid. ${ }^{1} \mathrm{H}$ NMR $\left(400 \mathrm{MHz}, \mathrm{C}_{6} \mathrm{D}_{6}, 298 \mathrm{~K}\right) \delta 7.66(1 \mathrm{H}, \mathrm{s}, \mathrm{CH}=\mathrm{CH}), 6.42(1 \mathrm{H}, \mathrm{s}, \mathrm{CH}=\mathrm{CH}), 4.90$ $\left(1 \mathrm{H}, \mathrm{s}, \mathrm{CH} \mathrm{Cp}_{\mathrm{A}}\right), 4.30\left(5 \mathrm{H}, \mathrm{s}, \mathrm{CH} \mathrm{Cp}_{\mathrm{B}}\right), 4.04\left(1 \mathrm{H}, \mathrm{d}, \mathrm{J}_{\mathrm{HH}}=12 \mathrm{~Hz}, \mathrm{CH}_{2}\right), 3.99$ $\left(1 \mathrm{H}, \mathrm{s}, \mathrm{CH} \mathrm{Cp}_{\mathrm{A}}\right), 3.94\left(1 \mathrm{H}, \mathrm{s}, \mathrm{CH} \mathrm{Cp}_{\mathrm{A}}\right), 3.52\left(3 \mathrm{H}, \mathrm{s}, \mathrm{ImCH}_{3}\right), 3.16(1 \mathrm{H}, \mathrm{d}$, $\left.\mathrm{J}_{\mathrm{HH}}=12 \mathrm{~Hz}, \mathrm{CH}_{2}\right), 2.22\left(6 \mathrm{H}, \mathrm{s}, \mathrm{N}\left(\mathrm{CH}_{3}\right)_{2}\right) .{ }^{13} \mathrm{C}\left\{{ }^{1} \mathrm{H}\right\} \mathrm{NMR}\left(100 \mathrm{MHz}, \mathrm{C}_{6} \mathrm{D}_{6}\right.$, 298 K) $\delta 218.56\left(\mathrm{C}^{\mathrm{q}}, \mathrm{N}-\underline{\mathrm{C}}-\mathrm{N}\right), 122.24(\mathrm{CH}, \underline{\mathrm{CH}}=\mathrm{CH}), 118.61(\mathrm{CH}, \mathrm{CH}=\underline{\mathrm{CH}})$, $100.99\left(\mathrm{C}^{\mathrm{q}}, \mathrm{Cp}_{\mathrm{A}}\right), 78.18\left(\mathrm{C}^{\mathrm{q}}, \mathrm{Cp}_{\mathrm{A}}\right), 70.77\left(5 \underline{\mathrm{CH}} \mathrm{Cp}_{\mathrm{B}}\right), 68.50\left(\underline{\mathrm{CH}} \mathrm{Cp}_{\mathrm{A}}\right)$,

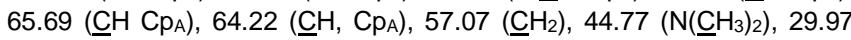
$\left(\operatorname{Im} \underline{\mathrm{CH}}_{3}\right)$.

Palladium complex (13) In a dry Schlenk tube, the imidazolium salt 7 (26 $\mathrm{mg}, 0.063 \mathrm{mmol})$ and $\left[\mathrm{PdCl}_{2}\left(\mathrm{MeCN}_{2}\right](17 \mathrm{mg}, 0.066 \mathrm{mmol})\right.$ were dissolved in dry MeCN $(30 \mathrm{~mL})$. tBuOK $(10 \mathrm{mg}, 0.089 \mathrm{mmol})$ was added and the mixture was heated at $50^{\circ} \mathrm{C}$ for $16 \mathrm{~h}$. The solvent was evaporated in vacuo, the residue taken up into acetone and the solution was filtered through Celite ${ }^{\circledR}$. After removal of the solvent, the residue was purified by precipitation, by addition of excess MTBE to a concentrated solution of $\mathrm{CH}_{2} \mathrm{Cl}_{2}$. The palladium complex 13 was obtained as a yellow solid $(10 \mathrm{mg}$, $32 \%$ yield). ${ }^{1} \mathrm{H}$ NMR $\left(400 \mathrm{MHz}, \mathrm{CDCl}_{3}, 298 \mathrm{~K}\right) \delta 7.46\left(1 \mathrm{H}, \mathrm{d}, \mathrm{J}_{\mathrm{HH}}=2 \mathrm{~Hz}\right.$ $\mathrm{CH}=\mathrm{CH}), 7.11\left(1 \mathrm{H}, \mathrm{d}, \mathrm{J}_{\mathrm{HH}}=2 \mathrm{~Hz}, \mathrm{CH}=\mathrm{CH}\right), 4.78\left(1 \mathrm{H}, \mathrm{s}, \mathrm{CH} \mathrm{Cp}_{\mathrm{A}}\right), 4.44(1 \mathrm{H}$, $\mathrm{s}, \mathrm{CH} \mathrm{Cp}$ ) $, 4.37\left(1 \mathrm{H}, \mathrm{t}, \mathrm{J}_{\mathrm{HH}}=2 \mathrm{~Hz}, \mathrm{CH} \mathrm{Cp} A\right), 4.21(5 \mathrm{H}, \mathrm{s}, \mathrm{CH} \mathrm{Cp}$ B) , 4.19 $\left(3 \mathrm{H}, \mathrm{s}, \mathrm{Im}-\mathrm{CH}_{3}\right), 3.32\left(1 \mathrm{H}, \mathrm{AB}\right.$ syst., $\left.\mathrm{J}_{\mathrm{HH}}=13 \mathrm{~Hz}, \mathrm{CH}_{2}\right), 3.23(1 \mathrm{H}, \mathrm{AB}$ syst., $\left.J_{\mathrm{HH}}=13 \mathrm{~Hz}, \mathrm{CH}_{2}\right), 2.96\left(3 \mathrm{H}, \mathrm{s}, \mathrm{N}-\mathrm{CH}_{3}\right), 2.84\left(3 \mathrm{H}, \mathrm{s}, \mathrm{N}-\mathrm{CH}_{3}\right) .{ }^{13} \mathrm{C}\left\{{ }^{1} \mathrm{H}\right\} \mathrm{NMR}$ $\left(100 \mathrm{MHz}, \mathrm{CDCl}_{3}, 298 \mathrm{~K}\right) \delta 154.23(\mathrm{Cq}, \mathrm{C}-\mathrm{Pd}), 123.90(\mathrm{CH}, \underline{\mathrm{CH}}=\mathrm{CH})$, $123.86(\mathrm{CH}, \mathrm{CH}=\underline{\mathrm{CH}}), 97.53\left(\mathrm{C}^{q} \mathrm{Cp}_{\mathrm{A}}\right), 77.80\left(\mathrm{C}^{q} \mathrm{Cp}\right), 70.44(5 \overline{\mathrm{CH}} \mathrm{Cp}$ ) $69.05\left(\mathrm{CH} \mathrm{Cp}_{\mathrm{A}}\right), 66.27\left(\mathrm{CH} \mathrm{Cp} \mathrm{p}_{\mathrm{A}}\right) 66.20\left(\mathrm{CH}_{2}\right), 63.19(\mathrm{CH} \mathrm{Cp}), 53.39(\mathrm{~N}-$ $\left.\underline{\mathrm{CH}}_{3}\right), 51.53\left(\mathrm{~N}-\underline{C H}_{3}\right), 39.12\left(\mathrm{Im}-\mathrm{CH}_{3}\right) . \mathrm{MS}(\mathrm{ESI}) \mathrm{m} / z 428\left[\mathrm{M}-\mathrm{HCl}_{2}\right]^{+}(100)$. HR-MS (ES+) calcd for $\mathrm{C}_{17} \mathrm{H}_{20} \mathrm{~N}_{3} \mathrm{FePd} 428.0051$, found 428.0054 .

Palladium complex (14) In a dry Schlenk tube, the imidazolium salt 8 (24 $\mathrm{mg}, 0.032 \mathrm{mmol})$ and $\left[\mathrm{PdCl}_{2}(\mathrm{MeCN})_{2}\right](12.3 \mathrm{mg}, 0.047 \mathrm{mmol})$ were dissolved in dry MeCN (30 mL). tBuOK ( $8 \mathrm{mg}, 0.071 \mathrm{mmol}$ ) was added and the mixture was heated at $50^{\circ} \mathrm{C}$ for $16 \mathrm{~h}$. The solvent was evaporated in vacuo, the residue taken up into acetone and the solution was filtered through Celite ${ }^{\circledR}$. After removal of the solvent, the residue was purified by precipitation, by addition of excess MTBE to a concentrated solution of acetone. Complex 14 was obtained as a yellow solid (10 mg, 32\% yield). ${ }^{1} \mathrm{H}$ NMR $\left(400 \mathrm{MHz}, \mathrm{CD}_{3} \mathrm{CN}, 298 \mathrm{~K}\right) \delta 7.49\left(1 \mathrm{H}, \mathrm{d},{ }^{3} \mathrm{~J}_{\mathrm{HH}}=2 \mathrm{~Hz}, \mathrm{CH}=\mathrm{CH}\right), 7.06$ (2H, s, CH Mes), 7.03 (2H, s. br., $\mathrm{CH}$ Mes), $6.39\left(1 \mathrm{H}, \mathrm{d},{ }^{3} \mathrm{~J}_{\mathrm{HH}}=2 \mathrm{~Hz}\right.$, $\mathrm{CH}=\mathrm{CH}), 6.28\left(1 \mathrm{H}, \mathrm{s}\right.$ br., $\left.\mathrm{CH} \mathrm{Cp}_{\mathrm{A}}\right), 5.86\left(1 \mathrm{H}, \mathrm{AB}\right.$ syst. ${ }^{2} \mathrm{~J}_{\mathrm{HH}=14 \mathrm{~Hz}}$, ImCH$\left.{ }_{2} \mathrm{Mes}\right), 5.52\left(1 \mathrm{H}, \mathrm{AB}\right.$ syst. $\left.{ }^{2} \mathrm{~J}_{\mathrm{HH}}=14 \mathrm{~Hz}, \mathrm{ImCH}_{2} \mathrm{Mes}\right) 4.08(2 \mathrm{H}$, s br., $\mathrm{CH}$ CpA), $4.64\left(1 \mathrm{H}, \mathrm{AB}\right.$ syst. $\left.{ }^{2} \mathrm{~J}_{\mathrm{HH}}=14 \mathrm{~Hz}, \mathrm{FcCH}_{2} \mathrm{~N}^{+}\right), 4.61(1 \mathrm{H}, \mathrm{AB}$ syst. $\left.{ }^{2} J_{\mathrm{HH}}=14 \mathrm{~Hz}, \mathrm{FCCH}_{2} \mathrm{~N}^{+}\right), 4.49\left(1 \mathrm{H}, \mathrm{AB}\right.$ syst. $\left.{ }^{2} \mathrm{~J}_{\mathrm{HH}}=14 \mathrm{~Hz}, \mathrm{~N}^{+} \mathrm{CH}_{2} \mathrm{Mes}\right), 4.44$ $\left(5 \mathrm{H}, \mathrm{s}, \mathrm{CH} \mathrm{Cp}_{\mathrm{B}}\right), 4.29\left(1 \mathrm{H}, \mathrm{AB}\right.$ syst. $\left.{ }^{2} \mathrm{~J}_{\mathrm{HH}}=14 \mathrm{~Hz}, \mathrm{~N}^{+} \mathrm{CH}_{2} \mathrm{Mes}\right), 2.72(3 \mathrm{H}, \mathrm{s}$, $\left.\mathrm{N}^{+} \mathrm{CH}_{3}\right), 2.44\left(3 \mathrm{H}, \mathrm{s}, \mathrm{N}^{+} \mathrm{CH}_{3}\right), 2.37\left(3 \mathrm{H}, \mathrm{s}, \mathrm{CH}_{3} \mathrm{Mes}\right), 2.36\left(3 \mathrm{H}, \mathrm{s}, \mathrm{CH}_{3} \mathrm{Mes}\right)$, $2.25\left(3 \mathrm{H}, \mathrm{s}, \mathrm{CH}_{3} \mathrm{Mes}\right), 2.23-2.19\left(9 \mathrm{H}, \mathrm{m}, \mathrm{CH}_{3} \mathrm{Mes}\right) \cdot{ }^{13} \mathrm{C}\left\{{ }^{1} \mathrm{H}\right\} \mathrm{NMR}$ (100MHz, $\mathrm{CD}_{3} \mathrm{CN}, 298 \mathrm{~K} \delta 149.97$ (Cq C-Pd), 141.56 (2 Cq Mes), 141.46 (Cq Mes), 140.37 (Cव Mes), 139.67 (2 $\mathrm{C}^{\mathrm{q}} \mathrm{Mes}$ ), 131.59 (CH Mes), 131.47 (CH Mes), 130.45 (CH Mes), 130.41 (CH Mes), 127.95 (Cq Mes), 125.58 ( $\mathrm{Im} \mathrm{CH}=\mathrm{CH}$ ), 122.91 (Cq Mes), 121.81 ( $\mathrm{Im} \mathrm{CH}=\mathrm{CH}), 99.21$ ( $\left.\mathrm{C}^{q} \mathrm{Cp}_{\mathrm{A}}\right), 73.25$ $(\mathrm{CH} \mathrm{Cp} A), 72.45(5 \mathrm{CH} \mathrm{Cp}), 72.37\left(\mathrm{CH} \mathrm{Cp}_{\mathrm{A}}\right), 69.21\left(\mathrm{CH} \mathrm{Cp} \mathrm{p}_{\mathrm{A}}\right), 67.38\left(\mathrm{C}^{\mathrm{q}}\right.$

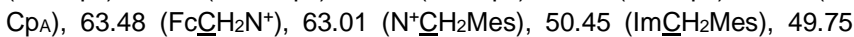
$\left(\underline{\mathrm{CH}}_{3} \mathrm{~N}^{+}\right), 49.16\left(\underline{\mathrm{C}} \mathrm{H}_{3} \mathrm{~N}^{+}\right), 21.81\left(2 o-\mathrm{CH}_{3} \mathrm{Mes}\right), 21.22\left(p-\mathrm{CH}_{3} \mathrm{Mes}\right), 20.96$

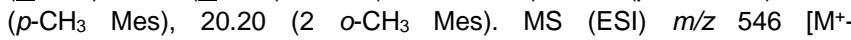
$\left.\left(\mathrm{C}_{10} \mathrm{H}_{13}\right)\left(\mathrm{CH}_{3} \mathrm{CN}\right) \mathrm{HCl}_{2}\right](60), 133\left[\mathrm{C}_{10} \mathrm{H}_{13}\right]^{+}$(100). HR-MS (ES+) calcd for $\mathrm{C}_{26} \mathrm{H}_{30} \mathrm{~N}_{3} \mathrm{FePd} 546.0836$, found 546.0837.

X-ray structural analyses. A single crystal of compound $\mathbf{2}$ was mounted under inert perfluoropolyether in a loop at the tip of a fiber and cooled in the cryostream of an Agilent Technologies GEMINI EOS CCD diffractometer. The structure was solved by direct methods (SIR97 [28]) and refined by least-squares procedures on $F^{2}$ using SHELXL-97 [29]. The cristal is twinned by reticular merohedy. The twin results from a 180.0 degree rotation about 1.0 . 0 . direct lattice direction: 
$\left[\begin{array}{lll}1.000 & 0.000 & 0.000\end{array}\right]$

$\left[\begin{array}{lll}-0.487 & -1.000 & 0.000\end{array}\right]$

$\left[\begin{array}{lll}0.000 & 0.000 & -1.000\end{array}\right]$

The two domains are in the ratio 1/4.All $\mathrm{H}$ atoms attached to carbon were introduced in calculation at idealized positions and treated as riding models. The drawing of the molecules was realized with the help of ORTEP32 [30].

Table 2. Crystal data and structure refinement for compound 2.

\begin{tabular}{|c|c|c|}
\hline Identification code & \multicolumn{2}{|l|}{2.} \\
\hline Empirical formula & \multicolumn{2}{|l|}{ C32 H38 Fe2 N6 } \\
\hline Formula weight & \multicolumn{2}{|l|}{618.38} \\
\hline Temperature & \multicolumn{2}{|l|}{$173(2) \mathrm{K}$} \\
\hline Wavelength & \multicolumn{2}{|l|}{$0.71073 \AA$} \\
\hline Crystal system & \multicolumn{2}{|l|}{ Triclinic } \\
\hline Space group & \multicolumn{2}{|l|}{$P-1$} \\
\hline \multirow[t]{3}{*}{ Unit cell dimensions } & $a=10.7001(4) \AA$ & $\alpha=82.391(2)^{\circ}$ \\
\hline & $b=11.7339(4) \AA$ & $\beta=89.823(2)^{\circ}$ \\
\hline & $C=11.8988(3) \AA$ & $V=102.838(3)^{\circ}$ \\
\hline Volume & \multicolumn{2}{|l|}{$1442.95(8) \AA^{3}$} \\
\hline Z & \multicolumn{2}{|l|}{2} \\
\hline Density (calculated) & \multicolumn{2}{|l|}{$1.423 \mathrm{Mg} / \mathrm{m}^{3}$} \\
\hline Absorption coefficient & \multicolumn{2}{|l|}{$1.038 \mathrm{~mm}^{-1}$} \\
\hline$F(000)$ & \multicolumn{2}{|l|}{648} \\
\hline Crystal size & \multicolumn{2}{|c|}{$0.3 \times 0.22 \times 0.18 \mathrm{~mm}^{3}$} \\
\hline Theta range for data collection & \multicolumn{2}{|l|}{3.013 to $27.103^{\circ}$. } \\
\hline Reflections collected & \multicolumn{2}{|l|}{32998} \\
\hline Independent reflections & \multicolumn{2}{|l|}{32998} \\
\hline Completeness to theta $=27.100^{\circ}$ & \multicolumn{2}{|l|}{$99.8 \%$} \\
\hline Refinement method & \multicolumn{2}{|l|}{$F^{2}$} \\
\hline Data / restraints / parameters & \multicolumn{2}{|l|}{$32998 / 0$ / 366} \\
\hline Goodness-of-fit on $F^{2}$ & \multicolumn{2}{|l|}{1.030} \\
\hline Final $R$ indices [l>2sigma(I)] & \multicolumn{2}{|c|}{$\mathrm{R} 1=0.0370, \mathrm{wR} 2=0.0811$} \\
\hline $\mathrm{R}$ indices (all data) & \multicolumn{2}{|c|}{$R 1=0.0492, w R 2=0.0893$} \\
\hline Largest diff. peak and hole & \multicolumn{2}{|c|}{0.549 and -0.404 e. $\AA^{-3}$} \\
\hline
\end{tabular}

CCDC-1028945 for compound 2 contains the supplementary crystallographic data for this paper. These data can be obtained free of charge from the Cambridge Crystallographic Data Centre via www.ccdc.cam.ac.uk/ data_request/cif.

\section{Acknowledgements}

We thank the CNRS and the Ministère de l'Enseignement Supérieur et de la Recherche (doctoral grant to P.L.) for financial support of this work.

Keywords: Carbene ligands • Ferrocenes $• \mathrm{~N}$ ligands $•$ Palladium

[1] Books: a) F. Glorius, N-Heterocyclic Carbenes in Transition Metal Chemistry, Springer-Verlag, Heidelberg, 2007; b) S. Díez-González, NHeterocyclic Carbenes: From Laboratory Curiosities to Efficient Synthetic Tools, RSC Publishing, Cambridge, 2010; Reviews: c) D. Bourissou, O. Guerret, F. P. Gabbaï, G. Bertrand, Chem. Rev. 2000, 100, 39-91; d) R. H. Crabtree, J. Organomet. Chem. 2005, 690, 5451 - 5457; e) F. E. Hahn, M. C. Jahnke, Angew. Chem. Int. Ed. 2008, 47, 31223172; f) S. Díez-González, N. Marion, S. P. Nolan, Chem. Rev. 2009 109, 3612-3676; g) L. Benhamou, E. Chardon, G. Lavigne, S. BelleminLaponnaz, V. César, Chem. Rev. 2011, 111, 2705-2733.

[2] a) W. A. Herrmann, Angew. Chem. Int. Ed. 2002, 41, 1290-1309; b) S. Díez-González, S. P. Nolan, Coord. Chem. Rev. 2007, 251, 874 - 883.

[3] a) C. W. K. Gstöttmayr, V. P. W. Böhm, E. Herdtweck, M. Grosche, W. A. Herrmann, Angew. Chem. Int. Ed. 2002, 41, 1363-1365; b) G. C Fortman, S. P. Nolan, Chem. Soc. Rev. 2011, 40, 5151-5169 ; c) E. A B. Kantchev, C. J. O'Brien, M. G. Organ, Angew. Chem. Int. Ed. 2007 46, 2768-2813; d) C. Valente, S. Çalimsiz, K. H. Hoi, D. Mallik, M. Sayah, M. G. Organ, Angew. Chem. Int. Ed. 2012, 51, 3314-3332; e) D. Yuan, H. V. Huynh, Organometallics 2010, 29, 6020-6027; f) F. Rajabi, W. R Thiel, Adv. Synth. Catal. 2014, 356, 1873-1877; g) J. J. Dunsford, K. J. Cavell, Organometallics 2014, 33, 2902-2905.

[4] a) V. César, S. Bellemin-Laponnaz, L. H. Gade, Chem. Soc. Rev. 2004, 33, 619-636; b) F. Wang, L. Liu, W. Wang, S. Li, M. Shi, Coord. Chem. Rev. 2012, 256, $804-853$

[5] a) N. Debono, A. Labande, E. Manoury, J.-C. Daran, R. Poli, Organometallics 2010, 29, 1879-1882; b) P. Loxq, N. Debono, S Gulcemal, J.-C. Daran, E. Manoury, R. Poli, B. Cetinkaya, A. Labande, New J. Chem. 2014, 38, 338-347.

[6] T. Hayashi, K. Yamamoto, M. Kumada, Tetrahedron Lett. 1974, 15, 4405 $-4408$

[7] a) T. Hayashi, M. Kumada, Acc. Chem. Res. 1982, 15, 395-401; b) T. Hayashi, M. Konishi, Y. Okamoto, K. Kabeta, M. Kumada, J. Org. Chem. 1986, 51, 3772-3781; c) W. R. Cullen, F. W. B. Einstein, C.-H. Huang A. C. Willis, E. S. Yeh, J. Am. Chem. Soc. 1980, 102, 988-993; d) A. N. Cammidge, K. V. L. Crépy, Chem. Commun. 2000, 1723-1724; e) A. N Cammidge, K. V. Crépy, Tetrahedron 2004, 60, 4377-4386; f) H. Liu, Y. Wu, Y. Zhao, Z. Li, L. Zhang, W. Yang, H. Jiang, C. Jing, H. Yu, B. Wang Y. Xiao, H. Guo, J. Am. Chem. Soc. 2014, 136, 2625-2629.

[8] B. Bildstein, M. Malaun, H. Kopacka, K. Wurst, M. Mitterböck, K.-H. Ongania, G. Opromolla, P. Zanello, Organometallics 1999, 18, 43254336

[9] A. Bertogg, F. Camponovo, A. Togni, Eur. J. Inorg. Chem. 2005, 347356.

[10] a) C. D. Varnado Jr, V. M. Lynch, C. W. Bielawski, Dalton Trans. 2009 7253-7261; b) E. L. Rosen, C. D. Varnado, A. G. Tennyson, D. M. 
Khramov, J. W. Kamplain, D. H. Sung, P. T. Cresswell, V. M. Lynch, C. W. Bielawski, Organometallics 2009, 28, 6695-6706.

[11] H. Plenio, J. Hermann, J. Leukel, Eur. J. Inorg. Chem. 1998, 1998, 20632069.

[12] B. Yucel, B. Sanli, H. Soylemez, H. Akbulut, J. Organomet. Chem. 2012, $704,49-64$.

[13] S. Özçubukçu, E. Schmitt, A. Leifert, C. Bolm, Synthesis 2007, 2007, 389-392.

[14] V. H. Purecha, N. S. Nandurkar, B. M. Bhanage, J. M. Nagarkar, Tetrahedron Lett. 2008, 49, 1384-1387.

[15] Y. Kuang, X. Sun, H. Chen, P. Liu, R. Jiang, Catal. Commun. 2009, 10, 1493-1496.

[16] H.-J. Cristau, P. P. Cellier, J.-F. Spindler, M. Taillefer, Chem. Eur. J. 2004, 10, 5607-5622.

[17] W. B. Cross, C. G. Daly, Y. Boutadla, K. Singh, Dalton Trans. 2011, 40, 9722-9730.

[18] a) R. A. Altman, E. D. Koval, S. L. Buchwald, J. Org. Chem. 2007, 72 , 6190-6199; b) R. A. Altman, S. L. Buchwald, Org. Lett. 2006, 8, 2779 2782.

[19] T. Mochida, Y. Miura, F. Shimizu, Cryst. Growth Des. 2011, 11, 262-268.

[20] M. Steurer, Y. Wang, K. Mereiter, W. Weissensteiner, Organometallics 2007, 26, 3850-3859.

[21] Above $\mathrm{pH} \mathrm{13,} \mathrm{the} \mathrm{imidazolium} \mathrm{is} \mathrm{deprotonated} \mathrm{and} \mathrm{the} \mathrm{carbenic} \mathrm{species}$ decomposes rapidly.

[22] a) B. Bildstein, M. Malaun, H. Kopacka, K.-H. Ongania, K. Wurst, J. Organomet. Chem. 1999, 572, 177-187; b) D. J. Kim, K. H. Oh, J. K Park, Green Chem. 2014, 16, 4098-4101.
[23] E. A. B. Kantchev, G.-R. Peh, C. Zhang, J. Y. Ying, Org. Lett. 2008, 10, 3949-3952.

[24] a) L. G. Bonnet, R. E. Douthwaite, R. Hodgson, J. Houghton, B. M. Kariuki, S. Simonovic, Dalton Trans. 2004, 3528-3535; b) J. Houghton, G. Dyson, R. E. Douthwaite, A. C. Whitwood, B. M. Kariuki, Dalton Trans. 2007, 3065-3073.

[25] a) S. Warsink, S. Y. de Boer, L. M. Jongens, C.-F. Fu, S.-T. Liu, J.-T. Chen, M. Lutz, A. L. Spek, C. J. Elsevier, Dalton Trans. 2009, 70807086; b) S. Warsink, P. Hauwert, M. A. Siegler, A. L. Spek, C. J. Elsevier Appl. Organometal. Chem. 2009, 23, 225-228.

[26] F. Tato, A. García-Domínguez, D. J. Cárdenas, Organometallics 2013, 32, 7487-7494

[27] a) Y.-M. Liu, Y.-C. Lin, W.-C. Chen, J.-H. Cheng, Y.-L. Chen, G. P. A Yap, S.-S. Sun, T.-G. Ong, Dalton Trans. 2012, 41, 7382-7389; b) M Mechler, K. Latendorf, W. Frey, R. Peters, Organometallics 2013, 32, 112-130.

[28] A. Altomare, M. Burla, M. Camalli, G. Cascarano, C. Giacovazzo, A Guagliardi, A. Moliterni, G. Polidori, R. Spagna, J. Appl. Cryst. 1999, 32, 115.

[29] G. M. Sheldrick, Acta Cryst. A 2008, 64, 112.

[30] a) M.N. Burnett \& C.K. Johnson, ORTEPIII, Report ORNL-6895 (1996). Oak Ridge National Laboratory, Tennessee, USA; b) L. J. Farrugia, J. Appl. Cryst. 1997, 30, 565 
Entry for the Table of Contents (Please choose one layout)

Layout 2:

\section{FULL PAPER}

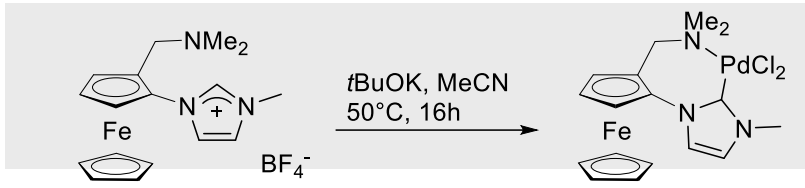

Two ferrocenyl imidazolium tetrafluoroborate salts $(R=$ Me and $(2,4,6$ trimethylphenyl)), precursors of new ferrocenyl imidazol-2-ylidene bifunctional ligands, and the corresponding palladium(II) complexes have been prepared for the first time.
Pauline Loxq, Jean-Claude Daran, Eric Manoury, Rinaldo Poli, Agnès Labande*

Page No. - Page No.

New Bifunctional N-Heterocyclic Carbene Ferrocenyl Ligands:

Synthesis and Palladium(II)

Complexes 